\title{
Composition and density of soil seed bank in Afar Region, Northeast Ethiopia
}

Wakshum Shiferaw Gemeda ( $D$ wakshumshiferaw@gmail.com )

Arba Minch University https://orcid.org/0000-0001-6075-3264

Sesebe Demissew Woodmata

Addis Ababa University

Tamrat Bekele M

Addis Ababa University

Ermias Aynekulu Betemariam

World Agroforestry Centre

Wolfgang Pitroff mm

GITEC, Ethiopia

Research article

Keywords: Prosopis juliflora, Invasion, Soil seed, Density, Pastoralists, Rangeland, West Afar, Ethiopia

Posted Date: July 30th, 2019

DOI: https://doi.org/10.21203/rs.2.12125/v1

License: (9) This work is licensed under a Creative Commons Attribution 4.0 International License.

Read Full License 


\section{Abstract}

Background: The changeover from seed to plant is a fundamental scheme shaping plant community structure and dynamics. Persistent soil seed banks are significant as it distributes regeneration and succession throughout the year in the vegetation ecosystems following disturbances. Objectives: The aims of our study were to analyze status of composition and density of soil seed banks (SBs) in West Afar Region, Ethiopia, and effects of Prosopis juliflora (Prosopis) on spatial distribution and densities of SBs. Methodology: Soil samples were collected under the Prosopis canopies and non-invaded open grazing lands from area of $15 \mathrm{~cm} \times 15 \mathrm{~cm}$ and soil layers of $0-3 \mathrm{~cm}, 3-6 \mathrm{~cm}$ and $6-9 \mathrm{~cm}$. Findings: It was found that SBs had shown significant variations by districts $(\chi 2=5.5, P=0.02)$ and soil layers $(X 2=10.5$, $P=0.01)$. But, habitats did not show significant effects on $S B s(X 2=2.3, P=0.13)$. Higher density of SBs 7065,8978 , and 8444 seeds $/ \mathrm{m} 2$, respectively were recovered from the soil depths of $0-3,3-6$, and $6-9 \mathrm{~cm}$ at Teru district. On the other hand, lower densities of 311,0 , and 44 seeds $/ \mathrm{m} 2$, respectively SBs were recovered from the soil depths of 0-3, 3-6, and 6-9cm were at Yalo district. Furthermore, SBs under the canopy of Prosopis were less by $93.5 \%$ than non-invaded open grazing lands in $0-3 \mathrm{~cm}$ soil depth. Meanwhile, SBs in $3-6 \mathrm{~cm}$ soil depth were higher by $79 \%$ in non-invaded Prosopis than invaded areas at Teru district. Conclusions: The overall low density of the SBs in the study areas had implications of poor range land quality for animals to feed on and consequently affects the livelihood incomes obtained from livestock of pastoralists. Thus, conservation of grazing lands, re-seeding of grazing lands, and management of the invasion of the Prosopis are vital measure to sustain the grazing areas in the region.

\section{Background}

The changeover from seed to plant is a fundamental scheme shaping plant community structure and dynamics [13]. However, in the long run of human-impacted landscapes [56] and different physiographic factors, vegetation forms a variety of different patterns both in the soil and standing vegetation after disturbances and colonized by aggressive invasive species [33]. Soil seed banks (SB) refers to a viable seed which is present in the soil or associated with hummus [34]. It represents the retentions of the last plant community and the improvement of future plant communities in the surrounding area [28]. The SBs are significant as a component of regeneration for succession in ecosystems following disturbances. Then, buried viable seeds germinate to cover the disturbed and exposed soil surfaces [51]. The formation of SB is a strategy developed by plants to prevent germination under unfavorable soil and climate conditions $[43,46]$. Thus, analyzing seed bank composition and density is important when communities have been invaded by exotic species and must be managed to promote the desired species [5].

Invasive species are introduced either purposely or naturally which are the second threat of global biodiversity loss the next to land-use changes [35]. Prosopis is one of the invasive plant species indigenous to South America, the Caribbean, and Central America [41]. Prosopis has been introduced consciously to Ethiopia particularly in the Afar Region in the late 1970s and 1980s [4, 1, 19, 57]. Although Prosopis has been giving use as fuelwood, shade and dry season fodder for the rural population, the 
threat posed by it in terms of invasion of fertile agricultural lands, prime grazing lands and loss of biodiversity are coming enormous [58].

In lowlands of Ethiopia, rangelands are subjected to different human and natural impacts. These facilitated for encroaching of undesirable herbaceous weeds and woody plants in rangelands that have become a threat to pastoral production systems [8]. Among woody encroachments, Prosopis is the most jeopardy to arid and semi-arid areas in the east and northeast Ethiopia particularly starting from early 1980's in Afar Region [44, 1, 45]. The study of SB is vital to know the progress of the Prosopis into other land use/cover and to alleviate/control from its further invasion in the areas. Land use/land cover changes, competitive ecological advantages, and climate change are key factors that are influencing the probability of Prosopis invasion [41, 45]. When an invasive species becomes firmly established, its control can often be difficult and eradication is usually impossible. Moreover, its impact on biodiversity and ecosystem processes can be very serious [44].

While comparing the above ground vegetation, investigations on the SBs were undervalued by many researchers all over the world [46]. The reason might be the difficulties in the isolation of viable seeds from the soil samples [2]. However, SB is an important component of ecosystem suppleness and represents a stock of regeneration potential in many plant collections. Understanding the diversity and density level of SB is important for designing conservation and restoration programs in degraded ecosystems particularly in the arid ecosystems. SBs are believed to lie mainly in the buried seed populations and therefore considered as essential constituents of plant communities since they reclaimed plant communities after disturbances [48].

Information of the SB is further essential for a better understanding of the species composition, capacity of storage size, seasonal changing aspects, and the distributing patterns which help to conserve and restore devastated and degraded vegetation types. As far as the biodiversity of below-ground flora and its relationship to extant vegetation are concerned, it is less understood by several scientists. Thus, In order to investigate complete diversity of plant communities in space and time, it is therefore vital to document SBs with above ground flora [46]. The study of SBs can also provide information about past management practices and their impacts on current and future vegetation. It also provides information about the former and apparent levels of degradation [26]. Therefore, SBs are essential for many plant communities and are recognized as an important part of management strategies for restoration such as drylands that permit species persistence during harsh times [13]. The invasive species exerts its effect not only on aboveground diversity but also on below-ground diversity [32]. Knowing seed bank composition and density is imperative when communities have been invaded by exotic species and have to be managed to promote desirable native species [6]. SB has been considered as a promising and cost effective method for restoring vegetation provided that there are no heavy disturbances and harsh climatic conditions. There are factors influencing SBs which have not yet been fully understood [28]. Thus, the possibility of vegetation restoration using the SB is basically dependent on its seed density and species composition $[12,17]$. On the other hand, seed dispersal is very important for species diversity, 
composition, and density. For instance, results showed that both livestock and wildlife species played a critical role in the dispersal of Prosopis and other native species [37].

Afar is one of the hottest and driest places in the world. Although it is severely affected by climatic variability, it is an area where a population has been living since time immemorial, adapting its pastoralist activities to changing environmental conditions [38]. Different land use/cover of the region with the invasions of Prosopis over time is threatening the pastoral mode of life. So far few studies have been investigated in Afar region by few researchers such as [44] in Middle Awash Rift Valley area, Kebede [24] at Allideghi Wildlife Reserve, Dessalegn [10], Haregeweyn et al. [20] about the analysis of the invasion rate, impacts and control measures of the Prosopis and llkor [59] in Gewane, Awash Fentale and Amibara districts.

Furthermore, no researches reported about the status of the SBs from the Teru and Yalo plains in the Afar Region of Ethiopia. SBs are important and largely undiscovered components of woodland and grassland vegetation dynamics. Moreover, update and quantitative information in relation to the effects of alien invasive woody species particularly Prosopis on SBs of native species are lacking. Changes in the aboveground plants after invasion are well documented than the issue of the changes of SB after invasions. On the other hand, the factors that modify the invasion effects of Prosopis along with other force variations such as physiographic and anthropogenic factors co-occur are unknown.

Therefore, the present study aims to analyze the horizontal and vertical distribution in composition and density of SBs in woodland and grasslands, and the effects of Prosopis on the spatial distribution and SB density in the region At the end, the study attempts to answer the following questions: (1) what are the status of the density and species diversity in SBs (1) what are the spatial variation in Prosopis in comparison to other native species in SB? (2) do Prosopis invasion modulates plant species composition, diversity, and density in the SBs in the West Afar Region (3) what is the future potential for sprouting and propagule sources for Prosopis? (4)What are the implications of the status of SBs for the restoration of rangelands?

\section{Results}

\section{Composition and density of soil seed banks}

In this study, high density of SBs were recovered from the 0-3cm (7065 individual seeds $\left./ \mathrm{m}^{2}\right), 3-6 \mathrm{~cm}$ (8978 seeds $\left./ \mathrm{m}^{2}\right)$, and $6-9 \mathrm{~cm}\left(8444\right.$ seeds $\left./ \mathrm{m}^{2}\right)$ soil depths at Teru district. However, the lowest densities of SBs were recovered at Yalo district. As the result, 222, 356, and 133 of seeds $/ \mathrm{m}^{2}$ in the $0-3 \mathrm{~cm}, 3-6 \mathrm{~cm}$, and $6-9 \mathrm{~cm}$ soil depths, respectively was germinated in greenhouse (Fig. 3).

With regard to the composition of SBs in those districts, only 10 species of plants were germinated. Most of these species were herbaceous $9(90 \%)$ and the rest $10 \%$ of the species was woody species. These plant species were distributed in the 8 families of plants (Table 1). Out of 8 species at Teru district, about $5(62.5 \%)$ of the species were found both in the $0-3 \mathrm{~cm}$ and $6-9 \mathrm{~cm}$ soil depths. Meanwhile, the rest $2(25 \%)$ 
were found in the $3-6 \mathrm{~cm}$ soil depth. On the other hand, out of 5 species found in Yalo districts, 2 (40\%), 1 $(20 \%)$, and $2(40 \%)$ were recovered from the $0-3 \mathrm{~cm}, 3-6 \mathrm{~cm}$, and $6-9 \mathrm{~cm}$ soil depths respectively (Table 1$)$.

Results also revealed that the highest SBs were recorded for Eragrostis cilcilianensis $6000 \mathrm{seeds} / \mathrm{m}^{2}$, and $5422 \mathrm{seeds} / \mathrm{m}^{2}$ in the depth of the $3-6 \mathrm{~cm}$, and $0-3 \mathrm{~cm}$, respectively in Teru district. Whereas the lowest SBs were recovered for Galinsoga parviflora that were 0 seeds $/ \mathrm{m}^{2}$ for the $3-6 \mathrm{~cm}$, and 44 seeds $/ \mathrm{m}^{2}$ for $0-3 \mathrm{~cm}$ and 3-9 soil depths each; and Prosopis (44 seeds $/ \mathrm{m}^{2}$ ) only in the $0-3 \mathrm{~cm}$ soil depth of Teru district (Table 1).

On the other hand, the status of the density of SBs at Yalo district was different from that of Teru district. In that district, the lowest SBs were recorded for Brachia riaovalis (44 of seeds $/ \mathrm{m}^{2}$ ) in $3-9 \mathrm{~cm}$ soil depth. Meanwhile, the highest density SBs were recovered relatively for Oxalis anthelmintica (356 of seeds $/ \mathrm{m}^{2}$ ) and Bidens pilosa (133 of seeds $/ \mathrm{m}^{2}$ ) in the study areas (Table 1 ).

Furthermore, Cypercaceae and Poaceae were the highest frequent families recorded in the study landscapes of Teru and Yalo districts. But, the lowest frequency families in SBs were recovered for the Crassulaceae, Oxalidaceae and Amaranthaceae families. In the present study, density of persistent SBs did not show clear trend across the soil depths in the study landscapes (Table 1).

Table 1. Composition and density soil seed bank at Teru and Yalo districts of West Afar Region 


\begin{tabular}{|c|c|c|c|c|}
\hline District & $\begin{array}{l}\text { Soil layer } \\
\text { (cm) }\end{array}$ & Scientific name & $\begin{array}{l}\text { SBs } \\
\text { density } / \mathrm{m}^{2}\end{array}$ & Family \\
\hline \multirow{12}{*}{ Teru } & $0-3$ & Galinsoga parviflora Cav. & 44 & Asteraceae \\
\hline & $6-9$ & G. parviflora & 44 & Asteraceae \\
\hline & $0-3$ & Prosopis juliflora (Sw.) DC. & 44 & Fabaceae \\
\hline & $0-3$ & Lipocarpha rehmannii (Ridl.) Goetgh. & 1422 & Cypercaeae \\
\hline & $3-6$ & L. rehmannii & 2978 & Cypercaeae \\
\hline & $6-9$ & L. rehmannii. & 3778 & Cypercaeae \\
\hline & $0-3$ & Physalis lagascae Roem. \& Schult. & 133 & Solanaceae \\
\hline & $6-9$ & P. lagascae & 3111 & Solanaceae \\
\hline & $0-3$ & $\begin{array}{l}\text { Eragrostis cilcilianensis (All.) Vign. Ex } \\
\text { Janchen }\end{array}$ & 5422 & Poaceae \\
\hline & $3-6$ & E. cilcilianensis (All.) Vign. Ex Janchen & 6000 & Poaceae \\
\hline & $6-9$ & E. cilcilianensis & 1289 & Poaceae \\
\hline & $6-9$ & Kalanchoe glaucescens Britten. & 222 & Crassulaceae \\
\hline \multirow{5}{*}{ Yalo } & $0-3$ & G. parviflora & 89 & Asteraceae \\
\hline & 0.3 & Bidens pilosa $\mathrm{L}$. & 133 & Asteraceae \\
\hline & $3-6$ & Oxalis anthelmintica A. Rich. & 356 & Oxalidaceae \\
\hline & $6-9$ & Brachiaria ovalis Stapf & 44 & Poaceae \\
\hline & $6-9$ & Amaranthus thunbergii Moq. & 89 & Amaranthacea $€$ \\
\hline
\end{tabular}

Notice: Soil seed banks is SBs

Effects of Prosopis on the soil seed banks

Table 2. Test statistics of soil seed banks by locations, habitat and soil depth in West Afar Region

\begin{tabular}{llll} 
Test statistics & District & Habitat & Soil layer \\
\hline$\chi^{2}$ & 5.5 & 2.3 & 10.5 \\
\hline $\mathrm{df}$ & 1 & 1 & 2 \\
\hline$P$-value & 0.02 & 0.13 & 0.01
\end{tabular}

Statistical analyses using non-parametric tests in Table 2 showed that SBs were varied by locations/districts $\left(\chi^{2}=5.5, P=0.02\right)$ and soil layers $\left(\chi^{2}=10.5, P=0.01\right)$. However, habitats did not 
significantly affect the SBs in the study areas $\left(\chi^{2}=2.3, P=0.13\right)$.

Results showed that even if the density of SBs in Prosopis invaded and non-invaded land use/land covers did not show significant, the total density of the SBs in the invaded areas were higher than that of non-invaded ones (Table 3). For instance, the SBs in the 6-9cm in the open grazing lands (non-invaded areas) were greater than 7000 seeds $/ \mathrm{m}^{2}$ than that of the highest SBs (seeds $/ \mathrm{m}^{2}$ ) in the soil depths of the Prosopis invaded land uses the Teru district. Whereas, the SBs in both soil layers and habitats in the Yalo districts were far lower than that of the density of Tero SBs (Fig. 3).

Furthermore, SBs in the Prosopis were less by $93.5 \%$ than the non-invaded open grazing lands in the 0$3 \mathrm{~cm}$ soil depth. Meanwhile, SBs in the $3-6 \mathrm{~cm}$ soil depth were higher by $79 \%$ in the non-invaded Prosopis than the invaded areas at Teru district. However, SBs in the $6-9 \mathrm{~cm}$ soil depths for the invaded areas were higher by $0.03 \%$ than that of the non-invaded by Prosopis in the Teru district (Table 3 ).

On the other hand, the SBs in non-invaded areas were greater by $60 \%$ in $0-3 \mathrm{~cm}$ soil layer than the invaded areas by Prosopisin Yalo districts. However, the same amounts of SB density were recorded in $3-6 \mathrm{~cm}$ soil depth in both the land uses in Yalo district. But, in this district the SBs density increased by $100 \%$ in the Prosopis areas than the non-invaded land uses in the $6-9 \mathrm{~cm}$ soil depth (Table 3).

Table 3. Density of soil seed banks in non-invaded and Prosopis invaded areas of Teru and Yalo districts, West Afar Region

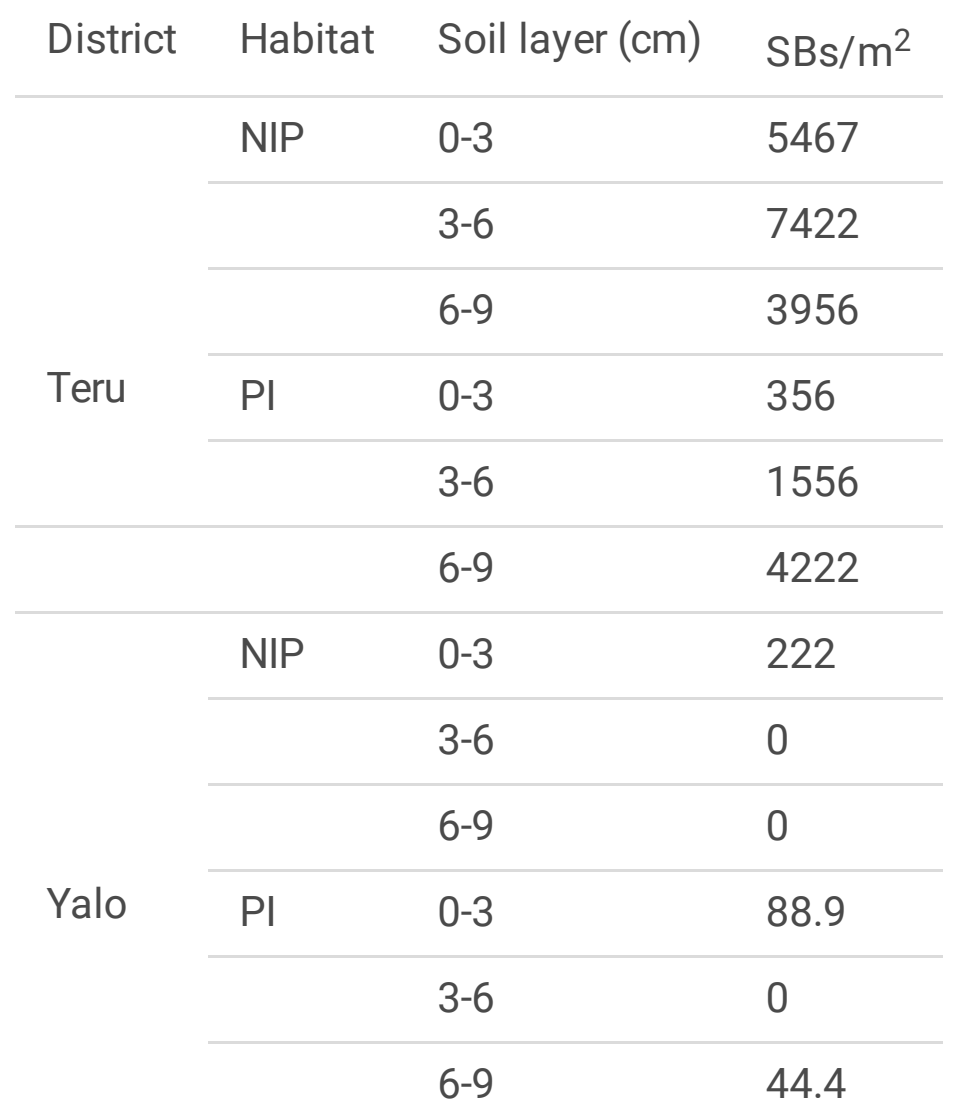




\section{Discussion}

Assessments of SBs have key relationships with understanding ecological processes for biological conservation. Moreover, SBs are influenced by propagule pressure and invasiveness in the invasion biology [2]. In this study, soil seeds could be discussed with persistence not the dormancy of seeds. This is because seed dormancy and persistence are different. Dormancy is thus the preciseness of the seeds about the germination conditions it require [50]. Thus, SBs especially persistent seeds offer plants the opportunity to disperse through time (Vandvik et al., 2016). In this study, most of the species germinated were herbaceous species like grass species [46].

In both districts the trends of the density of SBs were increasing from the top soil layer $(0-3 \mathrm{~cm})$ towards subsoil layers $(3-6 \mathrm{~cm}, 6-9 \mathrm{~cm})$. These might be due to the size of the seeds which moved down to the lower soil layers [46]. Moreover, the germination of the SBs in the lower soil layers might be the effects of soil depth hindered from emergence [9] and insufficiency of soil moisture to reach lower soil layers [61] Other reasons might be due to the effects of disturbance such as grazing of the study areas and harsh climatic conditions.

In both districts, the density of germinated in the SBs concerning the P.juliflora was negligible which might be due to its hard seed that could not break its mechanical dormancy $[44,24]$. Moreover, in those districts, animals might not the main agents which are involved in process of seed dispersal of the species. Because of the dispersal and successful germination of the seeds of $P$. juliflora is mainly facilitated through animal ingestion $[44,58,46]$. However, in this study due to financial limitations, we did not evaluate the composition and status of fecal droppings of wildlife on seed dispersal.

With compared to the density of the SBs of Teru districts, the density of SBs in Yalo district found to be very low. These could be due to the variations of the effects of the grazing [27], and human impact ([28] intensities for the two districts. While the number of soil seeds recovered in both districts were also low in comparison to other sites in the region and elsewhere in Ethiopia. The reasons might be due to temporal and spatial variations of the status of seeds in the soil [33], the effects in the variations of nutrient conditions [18], and potential of the seeds rains in the districts [62].

Moreover, lower rates of seed dispersal and unfavorable micro-climatic conditions like extreme high temperatures which contributed to higher mortality rates of seeds during rainy seasons are also identified as possible reasons for the lower density and richness of seeds in Yalo district than Teru district [40]. The variations in the density of SBs could also be due to the variations of altitudes in between the districts. At higher altitudes the density of seeds in soils are lower than that of low lying altitudes which is likely due to the effects of gravity and wind movement deposited seeds in lower altitudes [22]. On the contrary, densities of SBs are not altered by altitudes but no effects on species compositions of SBs [30].

In the present study, the density of SBs at Teru district greater than that of the density of seeds reported by [42] in the SBs of Northern Ethiopia and greater than [29] in China. However, the densities of SBs at 
Yalo district were lower than the aforementioned research reports in the Northern Ethiopia and in Mountain of China.

Moreover, the density of SBs at Teru district were ranged from $356 \mathrm{seeds} / \mathrm{m}^{2}$ in the invaded Prosopis to 7422 individual seeds $/ \mathrm{m}^{2}$ in the non-invaded open grazing lands which were lower than the density of SBs research made by Tekle and Bekele [49] in the degraded hill slopes in southern Wollo, Ethiopia. On the other hand, in this study the number of species emerged at both Teru and Yalo districts were lower than that of findings by Kelkay et al. [63] in a semi-arid African savanna, Tekle and Bekele [49] in Southern Wollo of Ethiopia, and Reubens et al. [42] in Northern Ethiopia. Moreover, the number of species recovered from the SBs in the present study areas was far lower than that of Dreber [11] in arid Nama Karoo rangelands in the South Africa. The SBs contained predominantly herbaceous species and woodland species were very few. These findings were similar with research report by Baum et al. [64] in northern Germany and central Sweden.

In the present study, the abundance and density of the SBs were lower in the invaded areas of the Prosopis than non-invaded open grazing lands of the districts. These could also be due to the allelochemical effects of the Prosopis $[16,41]$ and the effects of shade on the native species to produce sufficient seeds for dispersal [36]. The Prosopis is highly colonizing and invasive thorn tree species places vast amounts of seeds in the SB unlike other species [39] Moreover, findings made by Shiferaw et al. [44] in the Middle Awash of Ethiopia is greater than the density of the seeds recovered from the SBs at Yalo district but lower than that of Teru district in this study. In this study, the density of SBs in both districts was greater than research made by Kebede and Coppock [24] in Northeastern Ethiopia in both the invaded and non-invaded areas of Prosopis. In both districts, it was also found the density of SBs were higher than research reports by Andrade and Miranda [3] during November to May months in woody savanna of Central Brazil.

In general, the causes for the decline of both the SBs density and diversity in the present study of the West Afar Region might be due to large number of factors such as height, distance, and concentration of the seed source (seed rain), seed dispersal, nature and activity of dispersal agents and spatial heterogeneity of the parent plants in the field. These variations may also reflect differences among the species in terms of seed longevity in the soil, modes of seed dispersal and subsequent movement, seed predation, and probable differences in the slope of the landscape and local edaphic conditions where the seeds land [52].

\section{Conclusion}

In this study, a few numbers of the species and their low density in the soil seed banks at Yalo and Teru districts revealed that low opportunity for restoration of range lands in the future. Furthermore, the low status of density of seeds in the soil bank particularly at Yalo district had implications of grazing, human impact, disturbance intensities, and other limitations of edaphic factors (e.g. moisture stress, extreme high temperature, and low nutrients) in the study areas. 
On the other hand, the individual plant species such as Eragrostis cilcilianensis, Galinsoga parviflora, Lipocarpha rehmannii, Physalis lagascae, and Kalanchoe glaucescens at Teru district, and plant seeds like Brachiaria ovalis, Amaranthus thunbergii, Oxalis anthelmintica, and Bidens pilosa at Yalo district indicated that they were persistent in soil seed banks. These findings also showed the conservation and re-seeding of these species for restoration of the prime grazing areas in the region.

It was found that the invasion of Prosopis in this study and other studies clearly revealed variations in the diversity and density of native species in the SBs which ultimately affected the species composition of the range lands. Thus, low plant species composition for instance; low legume species in the pasture land also had implications low crude protein for grazers in the region. Consequently, the potential of drought animals and cows are harmed from low quality feeds. Therefore, the income of the pastoralists gained from dairy cows and beef production, and productivity will decline. To reverse these situations, conservation of grazing lands and management of the invasion of the Prosopis are vital measure to sustain the grazing areas in the region. Moreover, integrated management of the range land by range land manages in collaboration with the local communities are also the opportunities to control the Prosopis and rehabilitation of the range land areas. Thus, detail long-term effects of Prosopis on soil properties, above ground plant diversity, socioeconomics and phenology of Prosopis should be investigated in the future.

\section{Methods And Materials}

\section{Description of the study area}

The Afar Triangle is a cradle source of the earliest humankind. It contains a paleo-archaeological district that includes the Middle Awash region and numerous prehistoric sites of fossil hominin discoveries, including: the hominids and possible hominins, Ardi, or Ardipithecus ramidus, and Ardipithecus kadabba, the Gona (Gawis cranium) hominin; several sites of the world's oldest stone tools; Hadar, the site of Lucy, the fossilized specimen of Australopithecus afarensis, and Dikika, the site of the fossilized child Selam, an australopithecine hominin (White et al., 2009).

The Teru district is located $12^{\circ} 38^{\prime} 03.95^{\prime \prime} \mathrm{N}$ to $13^{\circ} 0^{\prime} .00^{\prime \prime} \mathrm{N}$ and $39^{\circ} 55^{\prime} .00^{\prime \prime} \mathrm{E}$ to $40^{\circ} 18^{\prime} 00.0^{\prime \prime} \mathrm{E}$ and at altitude of $354 \mathrm{~m}$ asl. Whereas, Yalo is located between $12^{\circ} 40^{\prime} 0^{\prime \prime} \mathrm{N}$ to $12^{\circ} 45^{\prime} 0^{\prime \prime} \mathrm{N}$, and $39^{\circ} 65^{\prime} 0.00^{\prime \prime} \mathrm{E}$ to $40^{\circ} 25^{\prime} .00^{\prime \prime}$ and at altitude of $826 \mathrm{~m}$ asl. Teru is one of the districts in the Afar Region in Ethiopia. Part of the Administrative Zone 4, Teru is bordered at south by Aura site, on southwest by Gulina, at west by Yalo, and at north and east by the Administrative Zone 2. The major settlement in this district is Alelo village acting as Town of Teru district (Fig.1).

Fifteen years of climate data were taken from the nearest meteorology station of the Melka Werer in the Amibra district of Afar Region in Ethiopia [14]. The mean annual temperature of the study areas was $26.8^{\circ} \mathrm{C}$. The recorded mean minimum annual temperature for the study areas was $13.8^{\circ} \mathrm{C}$. On the other hand, mean maximum annual temperature for the districts was $38.2^{\circ} \mathrm{C}$. The study areas are located 
within lowland agro-ecological zones of Ethiopia. The annual precipitation the study areas was about $416 \mathrm{~mm}$ (Fig. 2).

According to CSA [7], Yalo district has a total population of 47,468, of whom 27,319 are men and 20,149 women; with an area of 822.75 square kilometers, Yalo has a population density of 57.69 . While 790 or $1.66 \%$ are urban inhabitants, a further 9,730 or $20.50 \%$ are pastoralists. A total of 7,901 households were counted in this district, which results in an average of 6.0 persons to a household, and 8,105 housing units. $99.25 \%$ of the population said they were.

Geology of Afar floristic region is many Quaternary extrusive, intrusive and eolian formations. There are alluvial and colluvial deposits on the foot escarpments and Afar plains. Quite recent lava is found in the floristic region. The texture of the soils is usually sandy, originated from Jurassic and Cretaceous limestone and other sedimentary rocks. According to FAO soil classification and ISRIC-world soil information, the soil of Afar Floristic region is Lithic and Eutricleptosols, and Eutricfluvisols [15]. AcaciaCommiphora woodland and bushlandare were among vegetation types in Ethiopia which is characterizing the floristic region [15]. In the region, about $90 \%$ of Afar people are pastoralists, while another $10 \%$ are considered agro-pastoralist [54].

\section{Sampling design}

Sample site selection: Prosopis juliflora (Prosopis) invasions sites were categorized during preliminary reconnaissance survey. The sites have selected based on the local and national biodiversity importance of the native species and the severity of the threats by the invasive alien species of Prosopis. The study sites were stratified into approximately homogeneous units based on the following parameters: such invasion levels of Prosopis, the age of the species, land use land cover and physiography of the area. Soil samples for SBs were collected in August 2018 after Ethiopian Summer rainfall.

Sample plot layout: A total of 120 soil samples from 13 plots with a dimension of $15 \mathrm{~cm} \times 15 \mathrm{~cm}$ each from Prosopis invaded and non-invaded areas adjacent it (10 $\mathrm{m}$ apart) were taken from the same plots for the purpose the separation seeds from soil samples. The quadrats were laid in each Prosopis infestation levels from $0-3 \mathrm{~cm}, 3-6 \mathrm{~cm}$, and $6-9 \mathrm{~cm}$ soil depths. Accordingly, random soil samples were taken from soil depths. The water scheme of test plots for Prosopis invaded areas at Teru district were near Teru River. But, the test plots for open grazing lands at Teru district were adjacent to Prosopis invaded and also located near Teru River. On the other hand, the water schemes for both test plots Prosopis invaded and adjacent non-invaded open grazing lands were far away from rivers but near villages.

Data collection: Soil samples for seed bank analysis were collected using soil auger holding about $196.25 \mathrm{~cm}^{3}$ volume soil. Soil sample plots were distributed in different Prosopis invasion levels. Soil samples were carefully removed from five areas in each infection using a sharp knife [44]. Then, about $1 \mathrm{~kg}$ of composite and representative soil samples (about 5 cores) for each layer was put in plastic bags 
and labeled [60]. Sampling was completed within a week to avoid differences between habitats, and thus any temporal bias in seed availability and composition [31].

Seed germination and identification: Number of viable seeds in the soil samples and seed dispersal through droppings of animals was estimated by the seedling emergence technique under conditions favorable for germination $[9,31)$.In the laboratory, the soil from each sample was thoroughly sieved to $4 \mathrm{~mm}$ to remove organic litter, and then about half kilogram and $3 \mathrm{~cm}$ depth of soil were placed into plastic trays in the greenhouse in the Central Ethiopia Environment, Forestry and Climate Change Research center, Addis Ababa following Dalling et al. [9].

To prevent possible contamination of the soils with non-experimental seeds, trays were placed in a shade house established in an open site ( $<80 \%$ full sunlight) and covered by a layer of white plastic mesh $(<0.5$ $\mathrm{mm}$ aperture) and transparent nylon sheet [31]. Temperatures fluctuated between a minimum of $13^{\circ} \mathrm{C}$ and a maximum of $32^{\circ} \mathrm{C}$ [42]. The trays were watered at least three times a week to keep the soil moist [31]. The soil in each tray was watered to saturation every week in order to induce germination. Seedlings were identified and counted weekly until emergence ceased. Seedling emergences were recorded every day for at least 6 months $[42,31]$.

Specimens were transplanted on to other pots after seedlings were identified by accession numbers and local names as identifiers, then they were removed to minimize confusion with newly emerged plants and possible density effects on further germination Shiferaw et al. [44]. Each specimen was identified following identification using their photos and plant press in the herbarium and the published Flora of Ethiopia and Eritrea (volumes 1-8).

Data analyses and presentation: The data analysis of soil seed bank in the sites was organized by arranging and recording the data on the excel data sheet. Soil seed bank density, diversity, vertical distribution, and composition were analyzed using SPSS version 24 of non-parametric tests of $K$ independent samples [21] and Excel software. Then, histograms and tables are drawn using the Microsoft Excel Software.

\section{Declarations}

- Ethics approval and consent to participate: All authors are participating to contribute for the manuscript improvement all aspects.

- Consent to publish: All authors have agreement to publish this manuscript.

- Availability of data and materials: All data are available in the manuscript.

- Competing interests: All computing interests are shared by all authors

- Funding: No funding applicable 
- Authors' Contributions: All authors are equally contributed the inputs for the manuscript.

\section{Acknowledgements}

The authors are thankful to Arba Minch, Addis Ababa Universities, and GITEC Project for financing the project. The first author special thanks Afar pastoral communities for their cooperation and assistance during data collection. Department of natural resources management in pastoral and agro-pastoral districts of Teru and Yalo districts and Melka Werer Research Center of EIAR are highly acknowledged for material and human resources assistance during site selection and data collection.

\section{References}

1. Abebe Y (2012). Ecological and Economic Dimensions of the Paradoxical Invasive SpeciesProsopis juliflora and Policy Challenges in Ethiopia. Journal of Economics and Sustainable Development, 3(8), ISSN 2222-2855, iiste.org

2. Abella SR, Chiquoine LP, Vanier CH (2013).Characterizing soil seed banks and relationships to plant communities. Plant Ecology, 214:703-71, Doi: 10.1007/s11258-013-0200-3.

3. Andrade LAZ, Miranda HS (2014). The dynamics of the soil seed bank after a fire event in a woody savanna in central Brazil. Plant Ecology, 215(10):1199-1209, https://www.jstor.org/stable/24553805

4. Berhanu and Tesfaye (2006). The Prosopis juliflora Dilemma, Impact on Dry land Biodiversity and Some Controlling Methods, Journal of the Dry Lands, 1(2):158-164.

5. Cox RD, Allen EB (2007).Stability of exotic annual grasses following restoration efforts in southern California coastal sage scrub. Journal of Applied Ecology, 45:495-504, Doi: 10.1111/j.1365-2664, 01437.x.

6. Cox RD, Allen EB (2008). The composition of soil seed banks in southern California coastal sage scrub and adjacent exotic grassland. Plant Ecol, 198:37-46, Doi: 10.1007/s11258-007-9383-9.

7. CSA (2007).Population Projection of Ethiopia for All Regions at Woreda Level, Addis Ababa.

8. Dalle G, Brigitte LM, Isselstein J (2006). Encroachment of woody plants and its impact on pastoral livestock production in the Borana lowlands, southern Oromia, Ethiopia, East African Wild Life Society, Afr. J. Ecol., 44:237-246.

9. Dalling JW, Swaine MD, Garwood NC (1995).Effect of soil depth on seedling emergence in tropical soil seed-bank investigations. Functional Ecology, 9:119-121, http://www.jstor.org.

10. Dessalegn KT (2010). Assessment of rangeland degradation, its effect on soil seed bank flora and implications on carbon sequestration. A case study of Allaidege rangeland, Afar Region, Ethiopia, MSc Thesis, Haramaya University, pp22-139.

11. Dreber $N$ (2011). How best to quantify soil seed banks in arid rangelands of the Nama Karoo? Environ Monit Assess, 173:813-824, Doi: 10.1007/s10661-010-1425-4.

12. Duncan RP, Diez JM, Sullivan JJ, Wangen S, Miller AL (2009). Safe sites, seed supply, and the recruitment function in plant populations. Ecology, 90: 2129-2138. 
13. Espinosa Cl, Luzuriaga AL, Cruz MD, Montero M, Escudero A (2013). Co-occurring grazing and climate stressors have different effects on the total seed bank when compared to the persistent seed bank. Journal of Vegetation Science, 24:1098-1107.

14. Ethiopian Metrology Agency (EMA) (2018). The National Climate Data of Ethiopia. Addis Ababa, Ethiopia.

15. Friis I, Demissew S, Breugel PV (2010) Atlas of potential vegetation of Ethiopia. The Royal Danish Academy of Sciences and Letters, Biologiske Skrifter 58: 1-315.

16. Getachew S, Demissew S, Woldemariam T (2012). Allelopathic Effects of the Invasive Prosopis juliflora() DC on Selected Native Plant Species in Middle Awash, Southern Afar Rift of Ethiopia. Management of Biological Invasions, 3(2):105-114, Doi:

17. Gonzalez SL, Ghermandi L (2012). Comparison of methods to estimate soil seed banks: the role of seed size and mass. Community Ecology, 13(2):238-242.

18. Gough L, Bass H, McLaren JR (2015). Effects of increased soil nutrients on seed rain: a role for seed dispersal in the greening of the Arctic? Arctic, Antarctic, and Alpine Research, 47(1):27-34

19. Haji J, Mohammed A (2013).The economic impact of Prosopisjulifloraon agropastoral households of Dire Dawa Administration, Ethiopia. African Journal of Agricultural Research, 8(9): 768-779, Doi:5897/AJAR12.014.

20. Haregeweyn N, Tsunekawa, Tsubo M, Meshesha D,Melkie A (2013). Analysis of the invasion rate, impacts and control measures of Prosopisjuliflora: a case study of Amibara District, Eastern Ethiopia. Environ Monit Assess, 185: 7527-7542

21. IBM Corporation (1986, 2016). IBM SPSS Statistics 24 Core System User's Guide, USA printing.

22. Jalili A, Hamzeh'ee B, Asri Y, Shirvany A, Yazdani S, Khoshnevis M, Zarrinkamar F, Ghahramani, MA, Safavi R, Shaw S (2003). Soil seed banks in the Arasbaran Protected Area of Iran and their significance for conservation management. Biol. Conserv, 109:425-431.

23. Kebede AT (2009)." Sustaining the Allideghi Grassland of Ethiopia: Influence of Pastoralism and Vegetation Change",All Graduate Theses and Dissertations, Paper 309, http://digitalcommons.usu.edu/etd/309.

24. Kebede AT, Coppock DL (2015).Livestock-Mediated Dispersal of Prosopis juliflora Imperils Grasslands and the Endangered Grevy's Zebra in Northeastern Ethiopia. Rangeland Ecology \& Management, 68(5):402-407, Doi:10.1016/j.rama.2015.07.002.

25. Kent M, Coker P (1992). Vegetation description and analysis: A practical approach, pp 97 England.

26. Kiss R, Valko O, Tothmeresz B, Torok P (2017). Seed bank research in Central European grasslandsAN overview. In: Seed Banks: Types, Roles and Research. Chapter1, Murphy J (Ed.), Nova Science Publishers, Inc., pp 1-34, ISBN: 978-1-53610-388-5.

27. Koc A, Kerim MG, Ibrahim HE (2013). Soil seed bank pattern in highland rangelands of Eastern Anatolian Region of Turkey under grazing systems. Turkish Journal of Field Crops, 18(1):109-117. 
28. Li CD, Xiao B, Wang Q, Zheng R, Wu J (2017). Responses of Soil Seed Bank and Vegetation to the Increasing Intensity of Human Disturbance in a Semi-Arid Region of Northern China. Sustainability, 9: 18-37, Doi:3390/su9101837.

29. Li Q, Fang H, Cai Q (2011). Persistent soil seed banks along altitudinal gradients in the Qilian Mountains in China and their significance for conservation management. African Journal of Agricultural Research, 6(10):2329-2340, Doi: 10.5897/AJAR10.1099

30. Lippok D, Walter F, Hensen I, Beck SG, Schleuning M (2013). Effects of disturbance and altitude on soil seed banks of Tropical Montane forests. Journal of Tropical Ecology, 29:523-529, Doi: $10.1017 /$ S0266467413000667.

31. Lopez-Toledo, L, Martinez-RamosM (2011). The soil seed bank in abandoned tropical pastures: the source of regeneration or invasion? Revista Mexicana de Biodiversidad, 82:663-678.

32. Mack MC, D'Antonio CM (2003). The Effects of Exotic Grasses on Litter Decomposition in Hawaiian Woodland: The Importance of Indirect Effects. Ecosystems, 6: 723-738 DOI: 10.1007/s10021-0030119-y.

33. MadawalaHMSP, Ekanayake SK., Perera GAD (2016). Diversity, composition, and richness of soil seed banks in different forest communities at Dotalugala Man and Biosphere Reserve, Sri Lanka. Ceylon Journal of Science, 45(1): 43-55, Doi: http://dx.doi.org/10.4038/cjs.v45i1.7363.

34. Mekonnen MA (2016). SB and Natural Regeneration of Trees. Journal of Sustainable Development, 9:2, doi:10.5539/jsd.v9n2p73.

35. Miranda RQ, Oliveira MTP, Correia RM., Almeida-Cortez JS, Pompelli MF (2011).Germination of juliflora (Sw) DC seeds after scarification treatments. Plant Species Biology, 26: 186-192.

36. Mosbah M, Taieb T, Habib K. (2018). Invasive character of Prosopis juliflora facilitated by its Allelopathy and a wide mutualistic interaction with soil microorganisms. Journal of Biological Sciences, 18(3):115-123, Doi: 10.3923/ibs.2018.115.123.

37. ,Kinyamario JI, Omari JK., Wambua JK (2011).Patterns of seed dispersal and establishment of the invader Prosopis juliflora in the upper floodplain of Tana River, Kenya. African Journal of Range and Forage Science, 28(1): 35-41.

38. Nebro A, IA, Gardo IA, Varet J, Onyango S (2016). Community based geographical development perspectives in Afar: A new player Afar Region based geographical development company (AGAPI). Proceedings, 6th African Rift Geothermal Conference Addis Ababa, Ethiopia, 2nd $-4^{\text {th }}$ November 2016.

39. Obiri JF (2011). Invasive plant species and their disaster-effects in dry tropical forests and rangelands of Kenya and Tanzania. JAMBA: Journal of Disaster Risk Studies, 3(2):417-428.

40. Ooi MK.J (2012). Seed bank persistence and climate change. Seed Science Research, 22: 53-60, Doi: $10.1017 /$ S0960258511000407.

41. Pasiecznik NM, Felker P, Harris PJC, Harsh LN, Cruz G, Tewari JC, Cadoret K., Maldonado LJ (2001) The Prosopis juliflora - Prosopis -pallida Complex: A Monograph, HDRA, Coventry. p172, ISBN: 0 905343301 , UK. 
42. Reubens B, Heyn M, Gebrehiwot K, Hermy M, Muys B. (2007). Persistent Soil Seed Banks for Natural Rehabilitation of Dry Tropical Forests in Northern Ethiopia, Tropicultura, 25(4):204-214.

43. Saatkamp A, Pochlod P, Lawrence VD (2014).The Functional Role of Soil Seed Bank in Natural communities. CABI .Seeds: The Ecology of Regeneration in Plant Communities, 3rd Edition (ed. Gallagher, R.S.).

44. Shiferaw H, Teketay D, Nemomissa S (2004). Some Biological Characteristics That Foster the Invasion of juliflora (Sw.) DC.in Middle Awash Rift Valley Area, North-Eastern Ethiopia. Journal of Arid Environments, 58:135-154, www.elsevier.com.

45. Shiferaw W, Demissew S, Bekele T (2018a). Invasive alien plant species in Ethiopia: ecological impacts on biodiversity a review paper. Int J MolBiol, 3(4):171-178, Doi:

10.15406/ijmboa.2018.03.00072.

46. Shiferaw W, Demissew S, Bekele T (2018b). “Ecology of soil seed banks: Implications for conservation and restoration of natural vegetation": A review. International Journal of Biodiversity and Conservation, 10(10): 380-393 http://www.academicjournals.org/IJBC.

47. Sileshi D, Abraha B (2014). Assessment of Soil Seed bank Composition of Woody Species in Hgumbirda National Forest Priority Area, Northeastern Ethiopia. Ethiopian Journal of Science (MEJS), 6(1): 5-44.

48. Song G, Li, X, Hui R (2017). Effect of biological soil crusts on seed germination and growth of an exotic and two native plant species in an arid ecosystem. PLoS ONE, 12(10).https://doi.org/10.1371/journal.pone.0185839.

49. Tekle K, Bekele T (2000). The Role of Soil Seed Banks in the Rehabilitation of Degraded Hillslopes in Southern Wollo of Ethiopia. BIOTROPICA, 32(1): 23-32.

50. Thompson K., Ceriani RM, Bakker, JP, Bekker RM (2003). Are seed dormancy and persistence in soil related? Seed Sci. Res., 13: 97-100, Doi: 10.1079/SSR2003128.

51. Tiebel K., Huth F, Wagner S (2018). Soil seed banks of pioneer tree species in European temperate forests: a review. iForest, 11: 48-5, Doi:3832/ifor2400-011.

52. Uasuf A, Tigabu M, Oden PC (2009). Soil Seed Banks and Regeneration of Neo-tropical Dry Deciduous and Gallery Forests in Nicaragua, Biology of Neotropics, 299 (1), Sweden.

53. Vandvik V, Klanderud K, Meineri E, Maen IE, Topper J (2016). Seed banks are biodiversity reservoirs: species-area relationships above versus below ground. Oikos, 125: 218-228, Doi: 10.1111/oik.02022.

54. Wakie T, Evangelista P, Laituri M (2014) Mapping Current and Potential Distribution of Non- Native juliflorain the Afar Region of Ethiopia.Plos One, 3, 9(11), e112854, www.plosone.org.

55. Zergaw YA, Anke J, Detle M (2015) Ecosystem engineer unleashed: Prosopisjuliflorathreatening ecosystem services? Regional Environmental Change, 15: 155-167 Doi:1007/s10113-014-0616-x.

56. Zobel M, Kalamees R, Pussa K., Roosaluste E, Moora M (2007). Soil seed bank and vegetation in mixed coniferous forest stands with different disturbance regimes. Forest Ecology and Management, 250:71-76. 
57. Ayanu YZ, Anke J, Detle, M (2015) Ecosystem engineer unleashed: juliflora threatening ecosystem services? Regional Environmental Change, 15: 155-167, Doi: 10.1007/s10113-014-0616-x.

58. FAO (2006). Invasion of juliflora in India, In Problems posed by the introduction of P.juliflora species in selected countries, Italy Rome, pp13.

59. Ilukor,J., Rettberg S, Treydte A, Birner R (2016). To eradicate or not to eradicate? Recommendations on juliflora management in Afar, Ethiopia, from an interdisciplinary perspective. Policy and Practice, 6:14, Doi, 10.1186/s13570-016-0061-1.

60. Sileshi D, Abraha B (2014). Assessment of Soil Seed bank Composition of Woody Species in Hgumbirda National Forest Priority Area, Northeastern Ethiopia. Ethiopian Journal of Science (MEJS), 6(1): 5-44.

61. Tang, J., Busso, C.A., Deming, J., Wang, Y., Wu, D., Musa, A., Miao, R., Miao, C. (2016). Seed Burial Depth and Soil Water Content Affect Seedling Emergence and Growth of Ulmus pumila sabulosa in the Horqin Sandy Land. Sustainability, 8:68; Doi: 10.3390/su8010068.

62. Gross CL., Mackay D (2014). Two decades of demography reveals that seed and seedling transitions limit population persistence in a trans-located shrub. Annals of Botany, 114: 85-96, Doi:10.1093/aob/mcu082, available online at aob.oxfordjournals.org.

63. Kelkay ZT, Ejigu B, Nigatu L (2017). Tree species determine soil seed bank composition and its similarity with understory vegetation in a semi-arid African savanna. Ecological Processes, 6(9):1-16, Doi: 10.1186/s13717-017-0075-7.

64. Baum S, Weih M, Bolte A (2013). Floristic diversity in Short Rotation Coppice (SRC) plantations: Comparison between soil seed bank and recent vegetation. Appl Agric Forestry Res, 3 (63)221-228, Doi: 10.3220/LBF_2013_221-228.

\section{Figures}




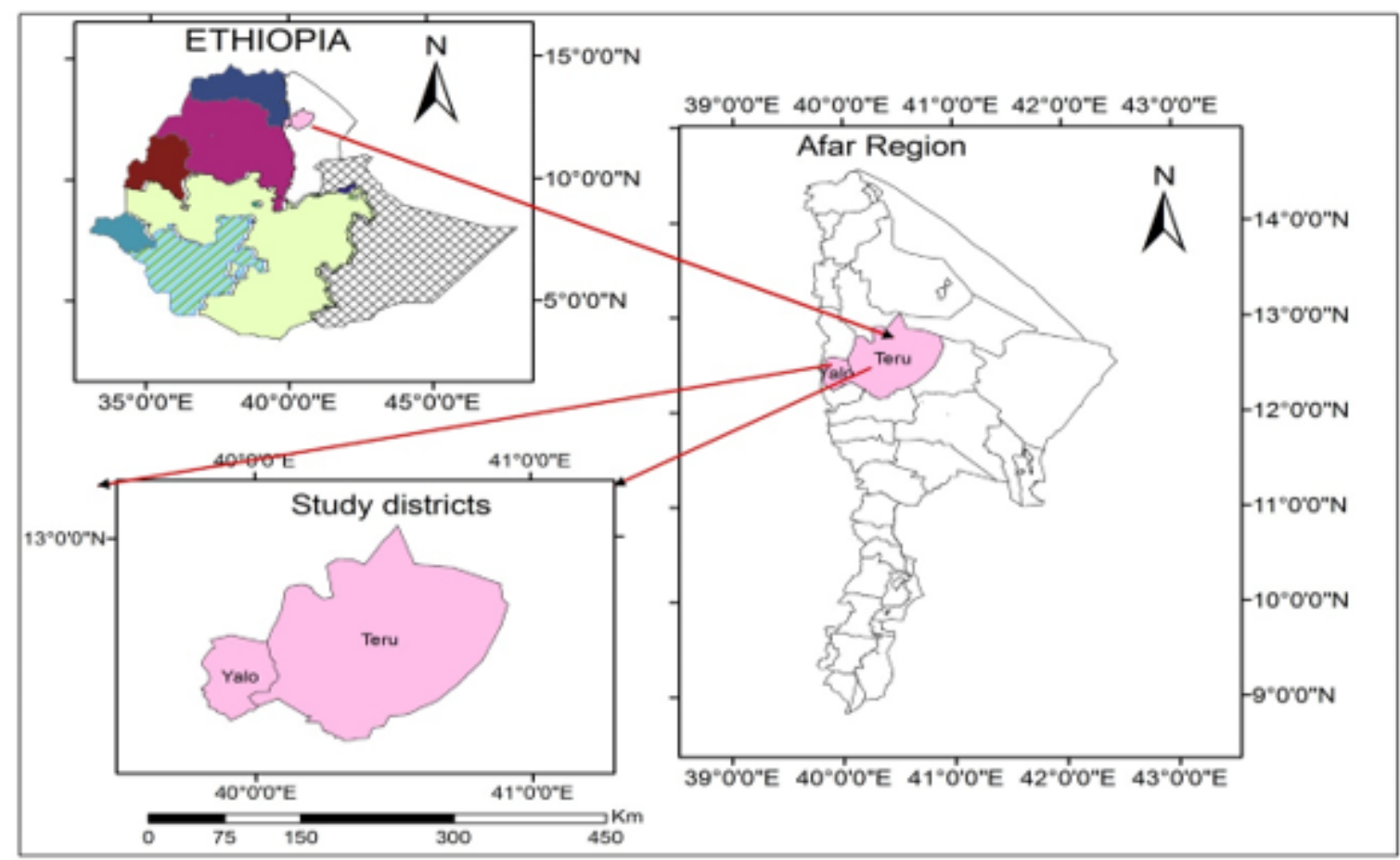

Figure 1

Map the study areas

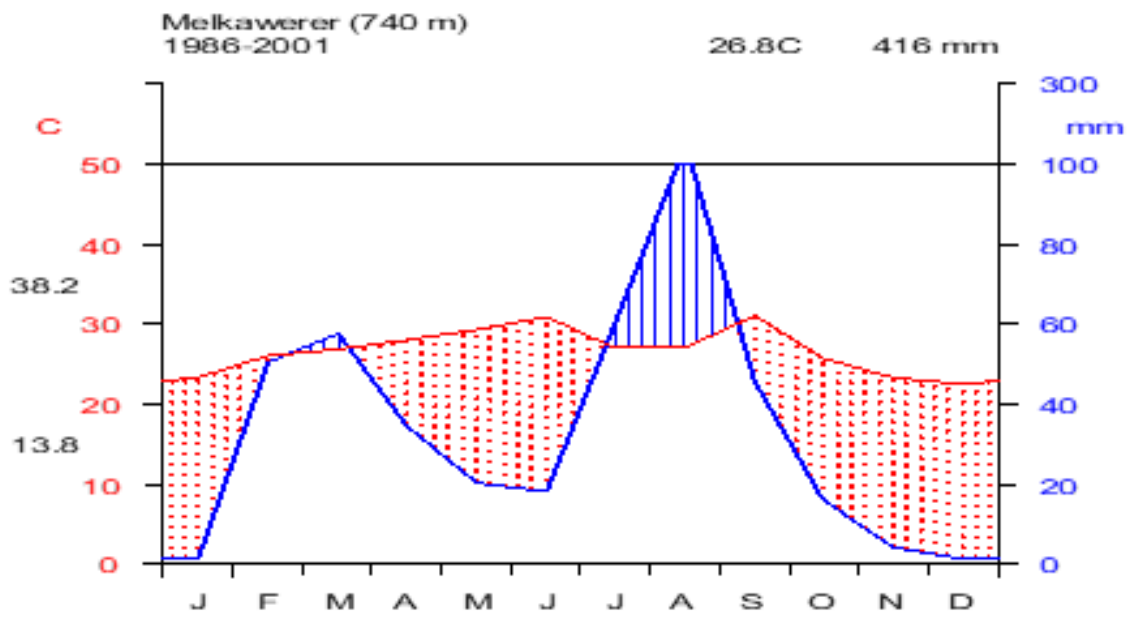

Figure 2

Fifteen years of climatic diagram for the study areas 


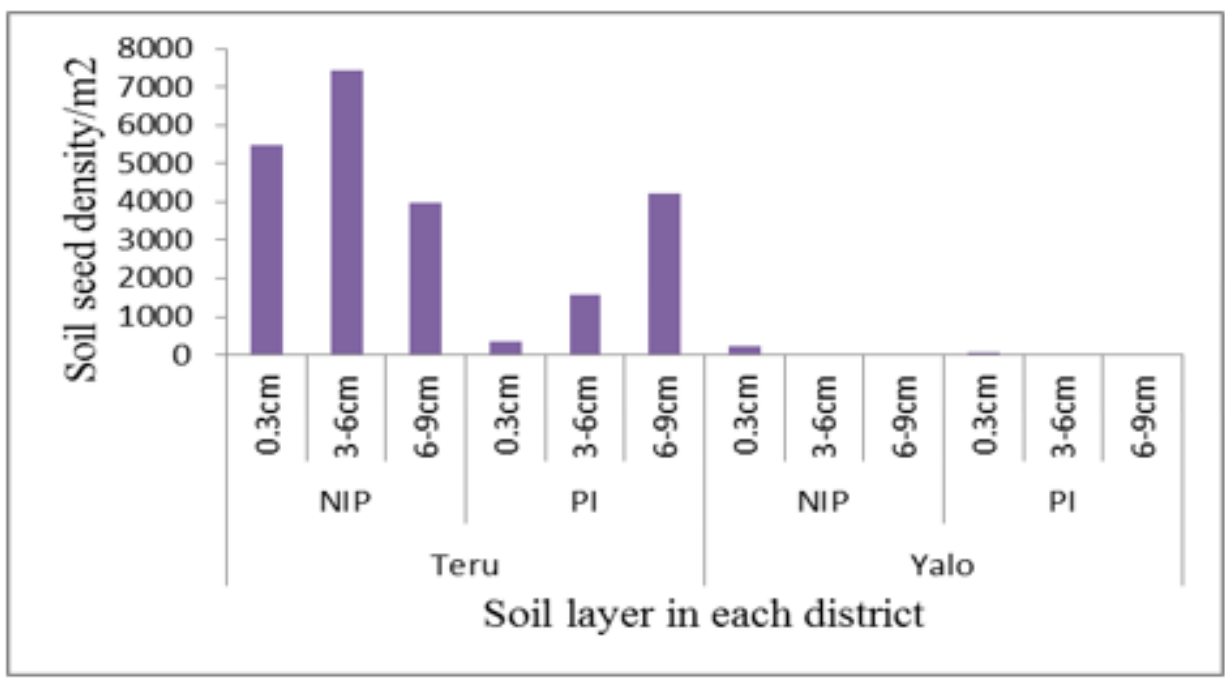

Notice: NIP is non-invaded by Prosopis, PI is invaded land use/cover

\section{Figure 3}

Density of soil seed bank at Teru and Yalo districts West Afar Region 